\title{
DETERMINATION OF THE FENVALERATE INSECTICIDE IN NATURAL WATERS BY A PHOTOCHEMICALLY-INDUCED FLUORESCENCE METHOD
}

\author{
Diène Diégane Thiaré ${ }^{1,2}$, Atanasse Coly ${ }^{1, *}$, Diégane Sarr ${ }^{1}$, Abdourakhmane Khonté ${ }^{1}$, Amadou Diop ${ }^{3}$, \\ Mame Diabou Gaye-Seye ${ }^{1}$, François Delattre ${ }^{2}$, Alphonse Tine ${ }^{1}$, Jean-Jacques Aaron ${ }^{4, *}$ \\ ${ }^{1}$ Laboratoire de Photochimie et d'Analyse (LPA), Faculté des Sciences et Techniques, \\ Université Cheikh Anta Diop, BP 5005, Dakar, Sénégal \\ ${ }^{2}$ Unité de Chimie Environnementale et Interactions sur le Vivant (UCEIV), ULCO, \\ BP 59140 Dunkerque, France \\ ${ }^{3}$ Laboratoire de Chimie Analytique et Bromatologie (LCAB), Faculté de Médecine de Pharmacie \\ et d'Odontologie, Université Cheikh Anta Diop, BP 5005, Dakar, Sénégal \\ ${ }^{4}$ Université Paris-Est Marne-la-Vallée, Laboratoire Géomatériaux et Environnement (LGE), EA 4508, \\ 5 Boulevard Descartes, 77454 Marne-La-Vallée, France \\ jeanjacquesaaron@yahoo.fr; tanoucoly@gmail.com
}

The fenvalerate pyrethroid insecticide was determined in various types of natural waters of Senegal by means of a newly-developed, simple, rapid and very sensitive photochemically-induced fluorescence (PIF) method. The PIF method was optimized with respect to the irradiation time, solvent and $\mathrm{pH}$. The obtained calibration curves yielded correlation coefficients very close to unity. The limit of detection $(\mathrm{LOD})$ and of quantification (LOQ) values were very low $(\mathrm{LOD}=0.01-0.66 \mathrm{ng} / \mathrm{ml}$ and $\mathrm{LOQ}=0.04-2.20$ $\mathrm{ng} / \mathrm{ml}$, according to the solvent), and the relative standard deviation (RSD) values were small, ranging between 0.1 and $1.5 \%$, which indicated a very good analytical sensitivity and a great repeatability of PIF. Recovery studies were performed on spiked distilled water, tap water, sea water, well water, river water and draining water samples of Senegal, using the liquid-liquid extraction (LLE), solid phase extraction (SPE), and standard addition procedures. Satisfactory recovery results (about 85-121\%) were obtained for the determination of fenvalerate in an aquatic environment.

Keywords: fenvalerate; insecticide; photochemically-induced fluorescence (PIF); aquatic environment

\section{ОПРЕДЕЛУВАНЕ НА ИНСЕКТИЦИДОТ ФЕНВАЛЕРАТ ВО ПРИРОДНИ ВОДИ СО ФОТОХЕМИСКИ ИНДУЦИАРАН ФЛУОРЕСЦЕНТЕН МЕТОД}

Пиретоидниот инсектицид фенвалерат е определен во различни типови природни води на Сенегал по пат на ново разработен, едноставен, брз и многу осетлив фотохемиски индуциран флуоресцентен (PIF) метод. Методот беше оптимизиран земајќи ги предвид времето на ирадијација, растворувачот и $\mathrm{pH}$. Добиените калибрациони криви дадоа коефициенти на корелација многу блиски до еден. Вредностите за границата на детекција (LOD) и границата на квантификација (LOQ) беа многу ниски (LOD = 0,01-0.66 ng/ml и LOQ = 0.04-2.20 ng/ml, во зависност од растворувачот) додека вредностите на релативната стандардна девијација (RSD) беа мали и се движеа од 1 до 1,5\%, што укажува на висока аналитичка сензитивност и одлична повторливост на PIF методот. Извршено е испитување на аналитичкиот принос на спајкувана дестилирана вода, вода од чешма, морска вода, изворска вода, речна вода и дождовница од Сенегал со примена на течно-течна екстракција (LLE), цврсто фазна екстракција (SPE) и со постапка на стандардни адиции. Беа добиени задоволувачки резултати за аналитичкиот принос (околу 85-121\%) за определување на фенвалерат во водна средина.

Клучни зборови: фенвалерат; инсектициди; фотохемиски индуцирана флуоресценција; водна средина 


\section{INTRODUCTION}

Fenvalerate is an insecticide that is widely used in the Senegalese "Niayes" region, an agricultural area located close to the north-western coast of Senegal. This molecule belongs to the pyre- throid chemical class and possesses two stereogenic centers due to the presence of two asymmetrical carbon atoms (Fig. 1). Thus, four stereoisomers of fenvalerate can be distinguished: $\alpha S 2 R$-, $\alpha R 2 S$-, $\alpha R 2 R$-, $\alpha S 2 S$-configurations [1, 2].

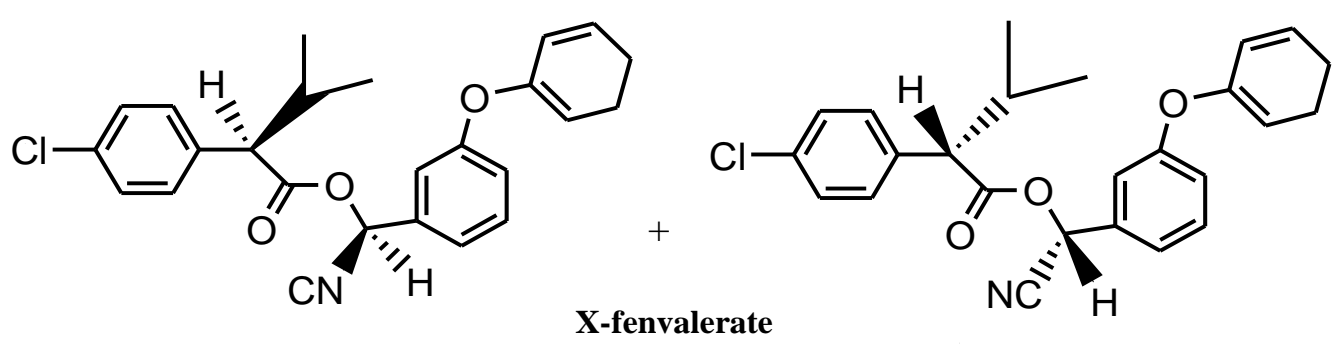

$\alpha \mathbf{S}$, 2R-fenvalerate

$\alpha \mathbf{R}, 2$-fenvalerate<smiles>CC(C)[C@H](C(=O)O[C@H](C)c1ccc(Cl)cc1)c1cccc(OC2=CCCC=C2)c1</smiles>

Y-fenvalerate<smiles>CC(C)[C@H](C(=O)O[C@H](C)c1ccc(Cl)cc1)c1cccc(OC2=CCCC=C2)c1</smiles>

$\alpha \mathbf{R}, \mathbf{2 R - f e n v a l e r a t e}$

$\alpha \mathbf{S}, \mathbf{2 S}$-fenvalerate

Fig. 1. Chemical structures of the four stereoisomers of fenvalerate

The four stereoisomers can be divided into two enantiomeric groups: the trans-enantiomeric pair ( $\alpha S, 2 R$-isomer and $\alpha R, 2 S$-isomer), also called $\mathrm{X}$-fenvalerate, and the cis-enantiomeric pair $(\alpha R$, $2 R$-isomer and $\alpha \mathrm{S}, 2 S$-isomer), also called $\mathrm{Y}$ fenvalerate [1]. $\alpha S, 2 S$-fenvalerate (esfenvalerate) exhibits the strongest insecticidal activity. This stereoisomer is produced and marketed under the ISO common name esfenvalerate [3]. Fenvalerate is practically insoluble in water $(2 \mu \mathrm{g} / \mathrm{l})$ and its solubility in acetone, chloroform, ethanol, and methanol is $>500 \mathrm{~g} / \mathrm{l}$ at $23{ }^{\circ} \mathrm{C}$, and $134 \mathrm{~g} / \mathrm{l}$ in hexane at $23{ }^{\circ} \mathrm{C}$ [4]. Three commercial formulations containing fenvalerate exist under the respective forms of emulsifiable concentrate, ultra-low volume and dry powder [5].

Several analytical studies have been performed to assess the presence of fenvalerate in various matrices, including vegetables [6, 7], fruit juice samples [8] and water $[5,9,10]$.

The most utilized analytical methods were high performance liquid chromatography (LC) and gas chromatography (GC). For instance, Martínez Galera et al. [11] simultaneously determined four pyrethroids, including fenvalerate, cypermethrin and cis-trans permethrin by HPLC in soil and groundwater samples, using the partial leastsquares (PLS-2) method. A solid-phase microextraction (SPME) analysis of seven pyrethroids, including fenvalerate, in groundwater samples was performed by LC combined with post-column photochemically-induced fluorimetry derivatization and fluorescence detection (SPME-LC-PIFFD) [12], yielding limits of quantification (LOQs), which varied between 0.03 and $0.075 \mu \mathrm{g} \mathrm{l}^{-1}$, according to the compound. However, these chromatographic methods present several disadvantages: they are relatively difficult to optimize and utilize, they often need either important solvent volumes or time-consuming chemical derivatization reactions, and they are relatively expensive.

Also, several non-chromatographic methods, such as visible absorption spectrophotometry [13, 14], flow injection-electrospray ionization-tandem mass spectrometry (FI-ESI-MS/MS) [15], flow injection analysis (FIA) with photo-induced fluorescence (PIF) detection [16-18], chemiluminescence (CL) $[19,20]$, and voltammetry [21] have 
been proposed for the determination of fenvalerate and other pyrethroid pesticides. For example, Tamrakar et al. [14] found that their spectrophotometric method allowed fenvalerate and cypermethrin to be determined in the presence of each other (after hydrolysis), and was rather sensitive and free from interferences of a number of foreign species. The FIA system with PIF detection, developed in organic solvents or in a micellar medium (sodium dodecyl sulfate, SDS), was reported as a particularly robust, sensitive (with LOD values in the $\mathrm{ng} \mathrm{ml}^{-1}$ range) and rapid (30-180 samples $\mathrm{h}^{-1}$ ) method for the determination of fenvalerate and other pyrethroid pesticides [1618]. Moreover, a highly-selective CL sensor, based on double-sided hollow molecularly imprinted microspheres, allowed Zang et al. [19] to determine fenvalerate by a flow injection CL method, with a LOD of $2.2 \times 10^{-8} \mathrm{~g} \mathrm{ml}^{-1}$, and to apply this CL method to real samples with satisfactory results.

The goal of this paper was to develop a simple, robust and rapid photo-induced fluorescence (PIF) analytical method, allowing one to easily determine fenvalerate in stationary solutions, and to apply it to the assessment of fenvalerate in natural waters. Indeed, fenvalerate is not naturally fluorescent; however, fluorescent photoproducts can be obtained by UV irradiation. As reported in several previous studies of our research group, the PIF method is based on the photochemical transformation of naturally non-fluorescent pesticides into fluorescent photoproduct(s) under UV irradiation [22-25]. In the present paper, we optimized our PIF method by fixing suitable excitation and emission wavelengths, and by investigating the effect of solvent and irradiation time on the fenvalerate PIF properties. We also established the analytical performances of the method. Moreover, to show the analytical usefulness of our PIF method, we applied it to the quantitative analysis of fenvalerate in spiked natural waters of Senegal, after liquid-liquid extraction, solid phase extraction and using the standard addition procedure.

\section{EXPERIMENTAL}

\subsection{Chemicals and reagents}

Stock standard solutions of fenvalerate $\left(10^{-3}\right.$ M) were freshly prepared by dissolving fenvalerate (99\%, PESTANAL ${ }^{\circledR}$, analytical standard, SigmaAldrich, Saint Quentin Fallavier, France) in acetonitrile. Solutions of $\mathrm{NaOH}(1.0 \mathrm{~mol} / \mathrm{l})$ and $\mathrm{HCl}$ ( $1.0 \mathrm{~mol} / \mathrm{l})$ were obtained by dissolving appropriate amounts of, respectively, sodium hydroxide $(97 \%$, $\mathrm{m} / \mathrm{m}$, Sigma-Aldrich Saint-Quentin Fallavier, France) and hydrochloric acid $(37 \% \mathrm{~m} / \mathrm{v}$, SigmaAldrich Saint-Quentin Fallavier, France) in distilled water, which were used for serial dilution. All solvents, including acetonitrile, ethyl acetate, ethanol, dichloromethane, dimethyl sulfoxide, cyclohexane, dimethylformamide and methanol were of spectroscopic grade and were also obtained from Sigma-Aldrich (Saint-Quentin Fallavier, France).

\subsection{Apparatus}

All spectral measurements were performed at room temperature on a Varian Cary Eclipse Fluorescence Spectrophotometer, interfaced with a computer. Here, 1-cm path length standard quartz fluorescence cells (Labo Moderne, France) were used for the fluorescence measurements, and a 20$1000 \mu$ l Pipetman micropipette (Gilson, France) was utilized for the dilutions. All analytical measurements were carried out under the same conditions of apparatus sensitivity, with excitation/emission slit widths $=10 / 10 \mathrm{~nm}$.

For the photolysis reactions, the photochemical set-up included a light box consisting of a fan, an Osram 200W HBO high-pressure mercury lamp, powered with an Oriel Model 8500 power supply, and a quartz lens. During photolysis, the quartz fluorescence cell was placed on an optical bench $40 \mathrm{~cm}$ from the mercury lamp.

\subsection{Methods and procedures}

\subsubsection{Preparation of solutions}

Here, $10^{-3} \mathrm{M}(420 \mu \mathrm{g} / \mathrm{ml})$ stock standard solutions of fenvalerate were freshly prepared by exactly weighting and dissolving the insecticide in acetonitrile.

The working standard solutions (concentrations in the range: $0.4-120.0 \mathrm{ng} / \mathrm{ml}$ ) were obtained by diluting the fenvalerate stock standard solution in the appropriate solvent or binary mixture. All solutions were protected against light with aluminum foil to avoid any decomposition and stored in a refrigerator.

\subsubsection{Photolysis reaction and PIF analytical measurements}

Photolysis reactions were performed by irradiating with UV light $3.5-\mathrm{ml}$ volumes of the fenvalerate working standard solutions for fixed periods of time at room temperature. Then, the PIF spectra were recorded at a scanning speed of 500 
$\mathrm{nm} / \mathrm{min}$. Curves of fluorescence intensity versus UV irradiation time were constructed at 1-min intervals, using the fenvalerate photoproduct constant excitation $\left(\lambda_{\mathrm{ex}}\right)$ and emission $\left(\lambda_{\mathrm{em}}\right)$ analytical wavelengths (see the irradiation time, $\lambda_{\mathrm{ex}}$ and $\lambda_{\mathrm{em}}$ values in Table 1). The statistical analysis of data was performed with OriginPro 8.5.1 software.

\subsubsection{Preparation of spiked water samples and standard addition procedure}

Water samples were collected in 1.5 liters amber glass bottles from natural waters (well, river, sea, and draining waters), located within the agricultural Niayes area. All samples were filtered by means of a syringe filter PTFE membrane (diameter $25 \mathrm{~mm}$; pore size $0.2 \mu \mathrm{m}$ - Sigma-Aldrich) in order to remove any suspended organic matter. For this, 10-ml volumes of natural water samples were spiked in flasks with known fenvalerate concentrations (range: $5.0-70.0 \mathrm{ng} / \mathrm{ml}$ ), included in the linear dynamic range of the calibration curves.

The standard addition procedure was performed, using the PIF method, as follows: eleven aliquots of $1.0-\mathrm{ml}$ portions of filtered natural water samples were initially spiked only one time with an appropriate volume $(5 \mu \mathrm{l})$ of fenvalerate stock standard acetonitrile solution. Then, these spiked aliquots of 1.0-ml portions of water samples were introduced into precision flasks, and increasing concentrations of fenvalerate working standard solutions (from 0.0 to $84.0 \mathrm{ng} / \mathrm{ml}$ ) were added to these flasks. After irradiation, the PIF signal was measured, and the fenvalerate concentration was determined by means of the calibration graph.

\subsubsection{Liquid-liquid extraction (LLE) and solid phase extraction (SPE) procedures}

In order to determine fenvalerate in the spiked natural water samples, we used the liquidliquid extraction (LLE) and the solid phase extraction (SPE) procedures.

The LLE procedure was performed with dichloromethane and ethyl acetate. A $10-\mathrm{ml}$ portion of spiked natural water sample containing 32.2 $\mathrm{ng} / \mathrm{ml}$ of fenvalerate was transferred into a $250 \mathrm{ml}$ separating funnel and extracted three times with 10 $\mathrm{ml}$ of the extraction solvent, and then gently evaporated down to a 10-ml volume. A 1-min optimum irradiation time value was used for irradiating this solution, the PIF intensity was measured and compared to the standard calibration curve, in order to determine the fenvalerate concentration.
The SPE procedure was carried out using a reverse-phase $\mathrm{C}_{18}$ cartridge with two elution solvents (MeCN or DMF). First, we conditioned the cartridge with $5 \mathrm{ml}$ of elution solvent, which allowed it to remain wet. Then, we loaded this cartridge with $5 \mathrm{ml}$ of a spiked natural water sample, containing either $25 \mathrm{ng} / \mathrm{ml}$ of fenvalerate in the case of $\mathrm{MeCN}$ or $20 \mathrm{ng} / \mathrm{ml}$ of DMF. Afterwards, the retained sample, spiked with fenvalerate, was eluted using $4 \mathrm{ml}$ of MeCN or DMF.

\section{RESULTS AND DISCUSSION}

\subsection{Photochemical reactivity and PIF properties of fenvalerate}

As mentioned above, fenvalerate exhibited no native fluorescence, while its UV irradiation yielded the formation of fluorescent photoproduct(s) in all media under study. The absence of native fluorescence of fenvalerate might be due, at least partially, to the following factors, inherent to its molecular structure (Fig.1): (i) the important flexibility of the molecule, with an obvious lack of rigidity, and therefore a tendency to be deactivated by thermal relaxation processes (collisions, etc.); (ii) the intramolecular heavy atom effect of the chlorine substituents, located on one of the aromatic rings of this molecule, which generally produces a strong decrease of the fluorescence quantum yield. Therefore, the formed fluorescent photoproduct might result from a dechlorination photochemical reaction of fenvalerate [26].

When submitting fenvalerate solutions to UV irradiation in our experimental conditions, we observed the appearance of PIF signal characterizing the formed photoproduct(s). We investigated the PIF behavior of fenvalerate in several solvents of strongly different polarities, including cyclohexane, dichloromethane, ethyl acetate, ethanol, methanol, acetonitrile, DMF, DMSO, water, and 50:50 $(\mathrm{v} / \mathrm{v})$ binary mixtures, including $\mathrm{EtOH}-\mathrm{H}_{2} \mathrm{O}$, $\mathrm{MeOH}-\mathrm{H}_{2} \mathrm{O}, \mathrm{MeCN}-\mathrm{H}_{2} \mathrm{O}$, DMF- $\mathrm{H}_{2} \mathrm{O}$, and DMSO$\mathrm{H}_{2} \mathrm{O}$. The results concerning the fenvalerate PIF spectral and photochemical properties $\left(\lambda_{\mathrm{ex}}, \lambda_{\mathrm{em}}, \mathrm{PIF}\right.$ intensity and optimal irradiation time) in these different media are reported in Table 1. As can be seen, these spectral and photochemical parameters were found to vary more or less importantly with the medium.

The shape of the PIF excitation and emission spectra was practically the same in all media, with a single, rather wide band. The PIF excitation maximum wavelengths were located between 278 and $287 \mathrm{~nm}$, whereas the emission maximum wave- 
lengths occurred in the range 321-336 nm, according to the solvent (Fig. 2 and Table 1). Therefore, taking into account the important changes of solvent polarity, we can consider that the $\lambda_{\mathrm{ex}}$ and $\lambda_{\mathrm{em}}$, values only weakly varied with the polarity of the medium. Also, the shape of the PIF spectra and the $\lambda_{\text {ex }}$ and $\lambda_{\text {em }}$, values did not change, irrespective of the fenvalerate initial concentration.

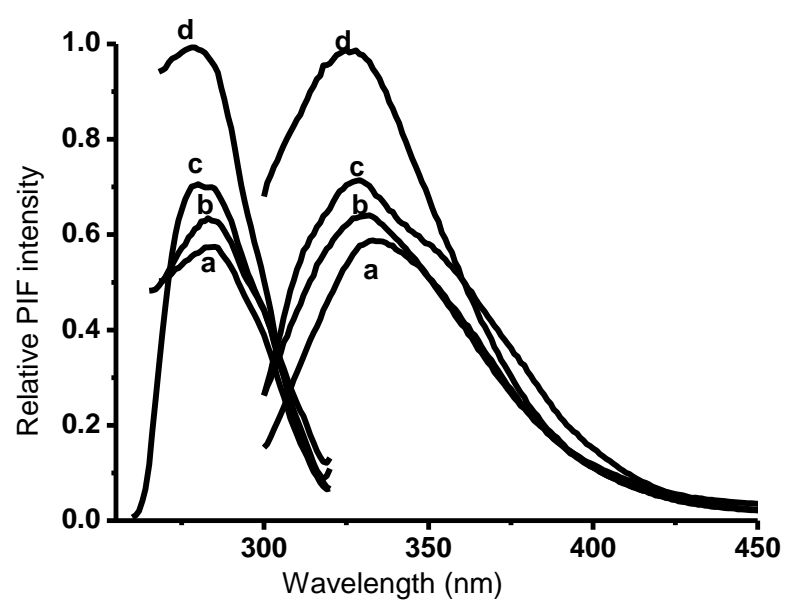

Fig. 2. PIF excitation spectra (left hand) and emission spectra (right hand) of fenvalerate $(63 \mathrm{ng} / \mathrm{ml})$ in acetonitrile (a), dichloromethane (b), dimethylformamide (c), and ethyl acetate (d)

In all media under study, we observed an increase of the PIF signal with the irradiation time. However, it is important to point out that the curves of variation of the PIF intensity $\left(\mathrm{I}_{\mathrm{PIF}}\right) v s$. the irradiation time $\left(\mathrm{t}_{\mathrm{irr}}\right)$ exhibited two different types of kinetic behaviors according to the solvent and/or mixture, which very probably indicated the existence of two distinct photodegradation reaction mechanisms (Fig. 3).

In the first type of kinetic behavior, the fenvalerate PIF signal strongly and rapidly increased with the irradiation time to reach a maximum value, corresponding to the optimal irradiation time, and then the PIF intensity decreased less rapidly (Fig. 3, curves (a) and (d), recorded in DMSO and cyclohexane, respectively). We can schematize the simplified two-step mechanism of the fenvalerate photodegradation as follows:

$$
\mathrm{FENV}+\mathrm{h} v \rightarrow \mathrm{P}_{1} \rightarrow \mathrm{P}_{2}
$$

with FENV $=$ fenvalerate, and $\mathrm{P}_{1}$ and $\mathrm{P}_{2}=$ fenvalerate photoproducts.

In the second type of behavior, the fenvalerate PIF signal more progressively increased with the irradiation time and, then stabilized in a plateau region, where it remained nearly constant (Fig. 3, curves (b) and (c), obtained in methanol and ethanol, respectively). In this case, no optimal irradiation time value could be defined. The simplified mechanism can be schematized as follows:

$$
\mathrm{FENV}+\mathrm{h} v \rightleftharpoons \mathrm{P}_{1} \rightleftharpoons \mathrm{P}_{3}
$$

with $\mathrm{P}_{1}$ and $\mathrm{P}_{3}=$ fenvalerate photoproducts.

These two distinct types of mechanism clearly show that at least one very fluorescent photoproduct is formed when the initial fenvalerate insecticide molecule is irradiated. In mechanism 1 , the first fluorescent photoproduct $\left(\mathrm{P}_{1}\right)$ would be progressively transformed into a second, nonfluorescent (or weakly fluorescent) photoproduct $\left(\mathrm{P}_{2}\right)$, whereas in mechanism 2, the fluorescent photoproduct $\mathrm{P}_{1}$ would reach a quasi-equilibrium state either with the initial herbicide molecule or, more probably, with a third, fluorescent photoproduct $\left(\mathrm{P}_{3}\right)$.

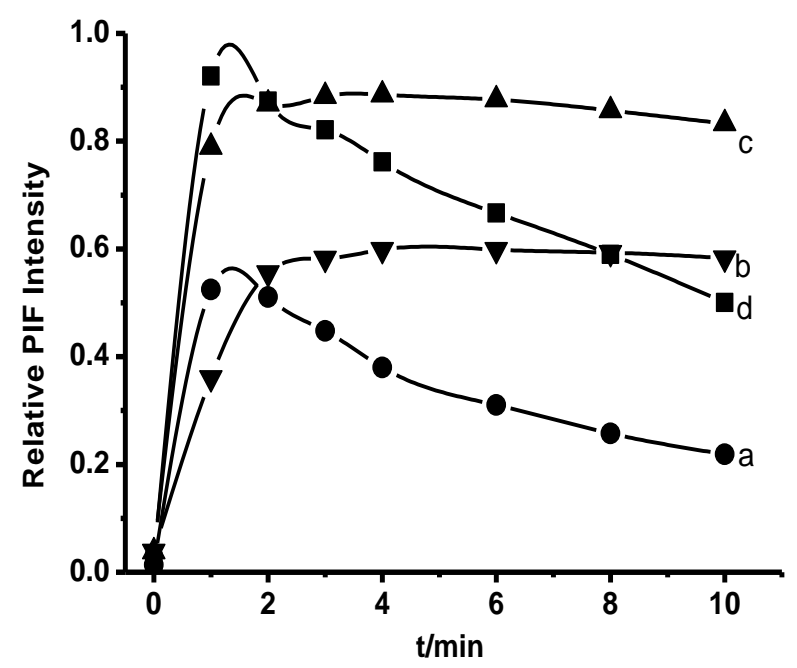

Fig. 3. Influence of the UV irradiation time on the PIF intensity of fenvalerate $(63 \mathrm{ng} / \mathrm{ml})$ in different solvents: DMSO (a), $\mathrm{MeOH}(\mathrm{b}), \mathrm{EtOH}(\mathrm{c})$ and cyclohexane (d)

\subsection{Development and optimization of the PIF analytical method}

In order to develop and optimize the PIF method for the determination of fenvalerate, we investigated the effect of the above-mentioned pure solvents and 50:50 (v/v) binary mixtures, on the fenvalerate PIF properties. The $\lambda_{\text {ex }}$ and $\lambda_{\text {em }}$ values changed very little with the medium, as already stated. In contrast, the optimum UV irradiation time ( $\left.t_{i r r}^{o p t}\right)$ and the normalized relative PIF intensity ( $\mathrm{I}_{\mathrm{PIF}}$ measured at $t_{\text {irr }}^{\text {opt }}$ ) values significantly 
varied with the polarity and polarizability of the solvents and binary mixtures (Table 1). The $t_{\text {irr }}^{\text {opt }}$ values ranged between 1 and 6 min according to the medium, which indicated remarkable differences of photochemical reactivity. As can be seen, these $t_{i r r}^{\text {opt }}$ values were shorter in aprotic solvents, such as cyclohexane, dichloromethane, ethyl acetate, acetonitrile, DMF and DMSO (1 min), and in 50:50 (v/v) binary mixtures with an aprotic component (1-2 $\mathrm{min})$ than in protic solvents, including methanol, ethanol and water (2-4 min), and in
$50: 50(\mathrm{v} / \mathrm{v})$ methanol and ethanol/water mixtures (5-6 min). On the other hand, for most solvents, the normalized relative PIF intensity values increased when the solvent dielectric constants $(\varepsilon)$ diminished, ranging in the following order: $\mathrm{I}_{\mathrm{PIF}}$ $\left(\right.$ EtOAc) $>I_{\mathrm{PIF}}(\mathrm{DMF})>I_{\mathrm{PIF}}\left(\mathrm{MeCl}_{2}\right)>I_{\mathrm{PIF}}$ (cyclohexane $)>I_{\mathrm{PIF}}(\mathrm{EtOH}) \sim I_{\mathrm{PIF}}(\mathrm{MeCN})>I_{\mathrm{PIF}}$ $(\mathrm{MeOH})>I_{\mathrm{PIF}}(\mathrm{DMSO})>>I_{\mathrm{PIF}}$ (water). The $\mathrm{I}_{\mathrm{PIF}}$ values of most organic solvent $-\mathrm{H}_{2} \mathrm{O} 50: 50(\mathrm{v} / \mathrm{v})$ binary mixtures were significantly smaller than those of the corresponding pure solvents.

Table 1

PIF spectral and photochemical properties of fenvalerate in the media under study

\begin{tabular}{|c|c|c|c|c|}
\hline Medium & $\varepsilon^{\mathrm{a}}$ & $\lambda_{\mathrm{ex} /} \lambda_{\mathrm{em}}(\mathrm{nm})^{\mathrm{b}}$ & $t_{\text {irr }}^{\text {opt }(\min )}{ }^{\mathrm{c}}$ & $\mathrm{I}_{\mathrm{PIF}}{ }^{\mathrm{d}}$ \\
\hline Cyclohexane & 2.1 & $285 / 321$ & 1 & 42.5 \\
\hline Ethyl acetate & 6 & $285 / 328$ & 1 & 62.5 \\
\hline Dichloromethane & 9.1 & $284 / 334$ & 1 & 42.6 \\
\hline $\mathrm{EtOH}$ & 24 & $280 / 325$ & 4 & 40.9 \\
\hline $\mathrm{MeOH}$ & 33 & $280 / 327$ & 4 & 27.6 \\
\hline $\mathrm{MeCN}$ & 37 & $285 / 333$ & 1 & 39.7 \\
\hline DMF & 38 & $282 / 328$ & 1 & 46.6 \\
\hline DMSO & 47 & $287 / 335$ & 1 & 24.2 \\
\hline Water & 80 & $278 / 325$ & 2 & 1.0 \\
\hline $\mathrm{EtOH}-\mathrm{H}_{2} \mathrm{O} 50: 50(\mathrm{v} / \mathrm{v})$ & - & $281 / 330$ & 6 & 41.3 \\
\hline $\mathrm{MeOH}-\mathrm{H}_{2} \mathrm{O} 50: 50(\mathrm{v} / \mathrm{v})$ & - & $285 / 328$ & 5 & 16.1 \\
\hline $\mathrm{MeCN}-\mathrm{H}_{2} \mathrm{O} 50: 50(\mathrm{v} / \mathrm{v})$ & - & $280 / 334$ & 2 & 34.7 \\
\hline DMF- $\mathrm{H}_{2} \mathrm{O} 50: 50(\mathrm{v} / \mathrm{v})$ & - & $283 / 336$ & 2 & 33.4 \\
\hline DMSO- $\mathrm{H}_{2} \mathrm{O} 50: 50(\mathrm{v} / \mathrm{v})$ & - & $285 / 328$ & 1 & 15.4 \\
\hline
\end{tabular}

From the analytical standpoint, in order to optimize the rapidity and sensitivity of PIF methods for the determination of fenvalerate, we decided to select pure organic solvents giving the shortest optimum irradiation times and the highest PIF signal values. In these conditions, the most suitable media were four aprotic solvents, namely ethyl acetate, DMF, dichloromethane, and acetonitrile, which yielded very short $t_{\text {irr }}^{\text {opt }}$ values $(1 \mathrm{~min})$ with relatively high $\mathrm{I}_{\mathrm{PIF}}$ values (Table 1).

\subsection{Analytical figures of merit}

Using the above-defined optimized analytical conditions, we evaluated the analytical figures of merit of fenvalerate in the selected solvents, including ethyl acetate, DMF, dichloromethane, and acetonitrile, which are reported in Table 2. All PIF analytical measurements were performed in triplicate for each concentration and in each solvent.

Linear calibration curves of PIF intensity vs. fenvalerate concentration were drawn at the analytical $\lambda_{\text {ex }}$ and $\lambda_{\text {em }}$ values by measuring the PIF height signal corresponding to the optimum irradiation time (Table 1). These calibrations curves were obtained over a linear dynamic range (LDR) of about one to two orders of magnitude according to the solvent (from $6.0-76 \mathrm{ng} / \mathrm{ml}$ in DMF to $0.5-114$ $\mathrm{ng} / \mathrm{ml}$ in acetonitrile), with correlation coefficient values very close to unity $\left(r^{2}=0.999\right)$, which indicates a good linearity of the PIF analytical curves. The limits of detection (LOD) values were calculated on the basis of a fenvalerate concentration giving a signal-to-noise ratio $(S / N)$ of 3 (IUPAC criterion). As can be seen in Table 2, the LODs significantly varied with the solvent, ranging from 
very low values of 0.01 and $0.02 \mathrm{ng} / \mathrm{ml}$ in dichloromethane and acetonitrile, respectively, to a higher value of $0.66 \mathrm{ng} / \mathrm{ml}$ in DMF. The limits of quantification (LOQ) values were calculated for an $\mathrm{S} / \mathrm{N}$ ratio of 10 (IUPAC criterion), and ranged from low values of 0.04 and $0.06 \mathrm{ng} / \mathrm{ml}$ in di- chloromethane and in acetonitrile, respectively, to a higher value of $2.20 \mathrm{ng} / \mathrm{ml}$ in DMF. The reproducibility of measurements, evaluated during five days with freshly-prepared solutions, was satisfactory, as shown by the small relative standard deviation (RSD) values ranging from 0.1 to $1.5 \%$.

T a b le 2

Analytical figures of merit for the PIF determination of fenvalerate

\begin{tabular}{lcccccc}
\hline \hline Solvent & $\lambda_{\mathrm{ex}} / \lambda_{\mathrm{em}}(\mathrm{nm})$ & $\mathrm{LDR}^{\mathrm{a}}(\mathrm{ng} / \mathrm{ml})$ & $\mathrm{LOD}^{\mathrm{b}}(\mathrm{ng} / \mathrm{ml})$ & $\mathrm{LOQ}^{\mathrm{c}}(\mathrm{ng} / \mathrm{ml})$ & $r^{2 \mathrm{~d}}$ & $\mathrm{RSD}^{\mathrm{e}}(\%)$ \\
\hline $\mathrm{MeCN}$ & $285 / 333$ & $0.5-114$ & 0.02 & 0.06 & 0.999 & 0.1 \\
$\mathrm{DMF}$ & $282 / 328$ & $6.0-76$ & 0.66 & 2.20 & 0.999 & 1.5 \\
$\mathrm{EtOAc}$ & $285 / 328$ & $2.0-70$ & 0.10 & 0.37 & 0.999 & 1.0 \\
$\mathrm{MeCl}_{2}$ & $284 / 334$ & $0.4-82$ & 0.01 & 0.04 & 0.999 & 0.1 \\
\hline \hline
\end{tabular}

${ }^{\mathrm{a}} \mathrm{LDR}=$ linear dynamic range.

${ }^{\mathbf{b}} \mathrm{LOD}=$ limit of detection, defined as the amount of analyte giving a signal-to-noise ratio of 3 .

${ }^{\mathbf{c}} \mathrm{LOQ}=$ limit of quantification, defined as the amount of analyte giving a signal-to-noise ratio of 10 .

${ }^{\mathrm{d}} r^{2}=$ correlation coefficient; ${ }^{\mathrm{e}} \mathrm{RSD}=$ relative standard deviation $(n=6)$.

Our analytical results indicate that the PIF method for the analysis of fenvalerate in organic solvents, such as dichloromethane and acetonitrile, is extremely sensitive. Indeed, the LOD and LOQ values obtained for fenvalerate with our PIF method were much lower than or close to those found by several authors, using LC with UV-visible photodiode array detection [11], photochemical spectrofluorimetry in acetonitrile solution (LOD $=8.7$ $\mathrm{ng} / \mathrm{ml}$ ) [27], PIF in sodium dodecyl sulfate (SDS) micellar medium (LOD $=7 \mathrm{ng} / \mathrm{ml}$ ) [26], PIF-flow injection analysis (PIF-FIA) (LOD $=4 \mathrm{ng}$ ) [16], and PIF-FIA in SDS (LOD $=1.05 \mu \mathrm{g} / \mathrm{ml}$ ) [18]. On the other hand, our LOD and LOQ values for fenvalerate were higher than those obtained by some other chromatographic methods, such as solid-phase microextraction coupled with LC and post-column PIF derivatization and fluorescence detection $($ SPME-LC-PIF-FD) $(\mathrm{LOD}=0.007 \mathrm{ng} / \mathrm{ml})$ [12].

\subsection{Analytical applications to the determination of fenvalerate in the aquatic environment}

To estimate the applicability of our PIF method to the determination of fenvalerate residues in tap and distilled water, and natural water samples (draining, sea, river and well waters, see Table 3 ), we performed recovery experiments on these water samples, which were spiked and analyzed as described in the Experimental Part. Fenvalerate was determined in spiked distilled water, tap water and natural water samples (draining, river and well waters) by means of the direct addition procedure, after using either liquid-liquid extraction (LLE) or solid phase extraction (SPE), procedures which are described in detail in the Experimental Part. The standard addition procedure was only utilized for the sea water samples. The physicochemical properties of the various natural water samples are presented in Table 3. As can be seen, these properties significantly changed with the type of water sample. For example, the physicochemical properties of sea water samples were characterized by dissolved organic carbon (NPOC, in $\mathrm{ng} / \mathrm{ml}$ ), conductivity $(\sigma$, in $\mathrm{S} / \mathrm{m})$ and $\mathrm{pH}$ values much higher than those of the other water samples. In addition, for most water samples (especially, for tap water, well water and sea water), the $\sigma$ values seemed to increase with the $\mathrm{pH}$ of medium.

\section{T a b le 3}

Physicochemical properties of the types of water samples under study

\begin{tabular}{lccc}
\hline \hline Sample & $\begin{array}{c}\mathrm{NPOC} \\
(\mathrm{ng} / \mathrm{ml})^{\mathrm{a}}\end{array}$ & $\begin{array}{c}\sigma \\
(\mathrm{S} / \mathrm{m})^{\mathrm{b}}\end{array}$ & $\mathrm{pH}$ \\
\hline Distilled water & 0.15 & 0.0001 & 7.01 \\
Tap water & 3.25 & 0.038 & 7.33 \\
Draining water & 2.95 & 0.009 & 6.71 \\
Sea water & 3.56 & 4.29 & 9.32 \\
River water & 1.43 & 0.007 & 6.89 \\
Well water & 1.23 & 0.090 & 8.31 \\
\hline \hline
\end{tabular}

${ }^{\text {a }} \mathrm{NPOC}(\mathrm{ng} / \mathrm{ml})=$ dissolved organic carbon, corresponding to the non-purgeable organic carbon (NPOC) present in natural waters, was calculated from the equation: $\mathrm{NPOC}=\mathrm{TOC}-$ POC, with TOC $=$ total organic carbon and $\mathrm{POC}=$ purgeable organic carbon.

${ }^{\mathbf{b}} \sigma(S / \mathrm{m})=$ water sample electrical conductivity 


\subsubsection{Analytical application and recovery determination after LLE}

The fenvalerate concentration and recovery values obtained after LLE are presented in Table 4 for the different water samples under study.

The recovery values, obtained for fenvalerate in distilled, tap and river water, using dichloromethane and ethyl acetate as extraction solvents, were acceptable, ranging from about 87 to $121 \%$. However, the fenvalerate determination in well water, draining water and sea water samples was not feasible, probably because of high matrix interferences in these samples. Therefore, we decide to apply a different, more suitable extraction procedure, namely the solid phase extraction.

\section{T a b le 4}

Analytical application of the PIF method to the determination of fenvalerate and recovery values in spiked water samples, after LLE

\begin{tabular}{llcc}
\hline \hline Solvent & Water sample & $\begin{array}{c}\text { Found concentra- } \\
\text { tion }(\mathrm{ng} / \mathrm{ml})\end{array}$ & Recovery $^{\mathbf{b}}(\%)$ \\
\hline \multirow{2}{*}{ Dichloromethane } & Distilled water & $32.1 \pm 0.9$ & $99.7 \pm 2.8$ \\
& River water & $39.0 \pm 0.7$ & $121.0 \pm 2.3$ \\
& Tap water & $33.2 \pm 0.5$ & $103.1 \pm 1.5$ \\
\hline \multirow{2}{*}{ Ethyl acetate } & Distilled water & $27.9 \pm 0.5$ & $86.7 \pm 1.7$ \\
& River water & $31.1 \pm 0.7$ & $96.5 \pm 2.2$ \\
\hline \hline
\end{tabular}

${ }^{a}$ Water samples were initially spiked with $32.2 \mathrm{ng} / \mathrm{ml}$ of fenvalerate.

b Triplicate measurements for each fenvalerate concentration.

\subsubsection{Analytical application and recovery deter- mination after SPE}

The SPE procedure was found to be more efficient than the LLE one, since it was able to correctly extract fenvalerate in the different natural water samples, whatever were their physicochemical properties (Table 3). Except in the case of sea water, the results obtained for the different natural water samples were rather satisfactory. Indeed, with the exception of sea water, the recovery val- ues were between 88 and $119 \%$ for $\mathrm{MeCN}$ as the elution solvent, and between 85 and $98 \%$ in the case of DMF (Table 5). The too high recovery value obtained in sea water (137.4\%), using $\mathrm{MeCN}$ as the elution solvent, was attributed to matrix interferences resulting from the higher values of dissolved organic carbon, conductivity and $\mathrm{pH}$ observed for this type of water sample. For this reason, we chose instead to use the standard addition procedure for the determination of fenvalerate in sea water.

Table 5

Analytical application of the PIF method to the determination of fenvalerate, and recovery values in spiked water samples, after SPE

\begin{tabular}{lcccc}
\hline \hline Elution solvent & \multicolumn{2}{c}{ MeCN } & \multicolumn{2}{c}{ DMF } \\
\hline Water sample $^{\mathbf{a}}$ & Found $(\mathrm{ng} / \mathrm{ml})$ & Recovery $^{\mathbf{b}}(\%)$ & Found $(\mathrm{ng} / \mathrm{ml})$ & Recovery $^{\mathbf{b}}(\%)$ \\
\hline Distilled water & $24.6 \pm 0.4$ & $98.4 \pm 1.6$ & $19.5 \pm 0.2$ & $97.7 \pm 1.2$ \\
Tap water & $32.6 \pm 0.9$ & $119.1 \pm 3.1$ & $19.2 \pm 0.37$ & $96.2 \pm 1.8$ \\
Draining water & $22.0 \pm 0.3$ & $88.4 \pm 1.4$ & $17.0 \pm 0.3$ & $85.0 \pm 1.7$ \\
Sea water & $31.9 \pm 0.9$ & $137.4 \pm 4.1$ & $17.7 \pm 0.2$ & $88.3 \pm 1.1$ \\
River water & $25.1 \pm 0.5$ & $100.4 \pm 2.0$ & $19.2 \pm 0.4$ & $96.2 \pm 2.2$ \\
Well water & $32.6 \pm 0.7$ & $118.1 \pm 2.5$ & $19.2 \pm 0.3$ & $96.2 \pm 1.5$ \\
\hline \hline
\end{tabular}

${ }^{a}$ Water samples were initially spiked with, $25 \mathrm{ng} / \mathrm{ml}$ and $20 \mathrm{ng} / \mathrm{ml}$ of fenvalerate, respectively, in the case of $\mathrm{MeCN}$ and of DMF.

${ }^{\mathbf{b}}$ Triplicate measurements for each fenvalerate concentration. 


\subsubsection{Analytical application and recovery deter- mination using standard addition procedure}

We utilized the standard addition procedure to determine fenvalerate in spiked sea water samples. Figure 4 shows the obtained calibration and standard addition curves. As can be seen, the slopes are very close, which demonstrates the absence of any significant interference from the matrix. The recovery values ranged from 99.8 to $112.3 \%$ (Table 6). In most instances, the accuracy was satisfactory for sea water samples.

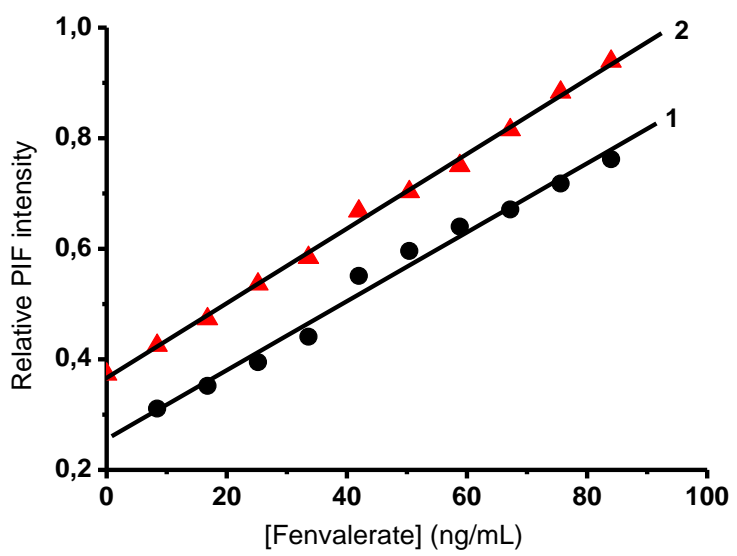

Fig. 4. Calibration curve (1) and standard addition curve (2) of fenvalerate in spiked sea water samples

Table 6

Analytical application of the PIF method to the determination of fenvalerate, and recovery values in sea water samples by means of the standard addition procedure

\begin{tabular}{ccc}
\hline \hline $\begin{array}{c}\text { Added } \\
(\mathrm{ng} / \mathrm{ml})\end{array}$ & $\begin{array}{c}\text { Found } \\
(\mathrm{ng} / \mathrm{ml})\end{array}$ & $\begin{array}{c}\text { Recovery } \\
(\%)\end{array}$ \\
\hline 0.0 & $16.7 \pm 0.2$ & - \\
8.4 & $26.0 \pm 0.2$ & 103.2 \\
16.8 & $35.6 \pm 0.3$ & 106.1 \\
25.2 & $46.1 \pm 0.2$ & 109.9 \\
33.6 & $56.5 \pm 0.4$ & 112.3 \\
42.0 & $61.3 \pm 0.6$ & 104.4 \\
50.4 & $67.0 \pm 0.2$ & 99.8 \\
58.8 & $77.1 \pm 0.4$ & 101.8 \\
67.2 & $83.8 \pm 0.3$ & 99.8 \\
75.6 & $96.4 \pm 0.5$ & 104.3 \\
84.0 & $108.9 \pm 0.2$ & 108.1 \\
Mean recovery $(\%)$ & & $105.0 \pm 4.2$ \\
\hline \hline
\end{tabular}

${ }^{\mathrm{a}}$ Triplicate measurements for each fenvalerate concentration.

\section{CONCLUSIONS}

We have shown the potential analytical usefulness of the solvent effect for improving the sensitivity of the PIF method for determining fenvale- rate in natural water samples. We have obtained good analytical figures of merit, which can permit the detection and quantification of fenvalerate in the $0.5-110 \mathrm{ng} \mathrm{ml}^{-1}$ range in aquatic environments. Our PIF method also compares favorably in terms of simplicity, rapidity and sensitivity with analytical results found by other, more expensive, timeconsuming and sophisticated methods, such as LC and GC [11]. The analytical applications to the determination of fenvalerate in spiked natural waters of Senegal have also led to satisfactory recovery values.

Acknowledgement. D. D. Thiaré thanks the Service of Cooperation and Cultural Action of the Embassy of France for financial support during his stay in the French University of the Littoral Côte d'Opale at Dunkerque.

\section{REFERENCES}

[1] Z. Li, Z. Zhang, L. Zhang, L. Leng, Isomer and enantioselective degradation and chiral stability of fenpropathrin and fenvalerate in sols. Chemosphere 76, 509-516 (2009).

[2] G. E. Schneiders, Acceptability of fenvalerate confined crop rotation and field studies to support esfenvalerate uses. Study \#129979. E. I. duPont de Nemours and Company, 1994.

[3] International Organization of Standardization (ISO), Pesticides and other agrochemicalsCommon names. ISO 175O:1981/Draft Addendum 5, Geneva, Switzerland, 1984.

[4] WHO data sheets on pesticides, $\mathrm{N}^{\circ} 90$, Fenvalerate, July 1996, www.inchem.org/documents/pds/pds/pest90_e.htm

[5] B. L. Swaroop, K. S. Kumar, K. Suvardhan, D. Rekha, P. Chiranjeevi, Analysis of fenvalerate in its formulations and environmental samples using spectrophotometry. J. Anal. Chem. 61, 755-759 (2006).

[6] S. B. Sing, I. Mukherjee, J. Maisnam, P. Kumar, M. Gopal, G. Kulshrestha, Determination of pesticide residues in integrated pest management and nonintegrated pest management samples of apple (Malus pumila Mill). J Agric Food Chem. 57, 11277-11283 (2009).

[7] A. K. Srivastava, P. Trivedi, M. K. Srivastava, M. Lohani, L. P. Srivastava, Monitoring of pesticide residues in market basket samples of vegetables from Lucknow City. India: QuEChERS method. Environ. Monit. Assess. 176, 465-472 (2011).

[8] S. Boonchiangma, W. Ngeontae, S. Srijaranai, Determination of six pyrethroid insecticides in fruit juice samples using dispersive liquid-liquid microextraction combined with high performance liquid chromatography. Talanta 88, 209-215 (2012). 
[9] Q. Chang, T. Feng, S. Song, X. Zhou, C. Wang, Z. Wang, Analysis of eight pyrethroids in water samples by liquid-liquid microextraction based on solidification of floating organic droplet combined with gas chromatography. Microchim. Acta 171, 241-247 (2010).

[10] M. L. Feo, A. Ginebrada, E. Eljarrat, D. Barcelo, Presence of pyrethroid pesticides in water and sediments of Ebro River Delta. J. Hydrology, 393, 156-162 (2010).

[11] M. Martinez Galera, J. L. Martinez Vidal, A. G. Frenich, M. D. Gil Garcia, Determination of cypermethrin, fenvalerate and cis-and transpermethrin in soil and groundwater by highperformance liquid chromatography using partial least-squares regression. J. Chromatogr. A 727, 39-46 (1996).

[12] P. Parrilla Vázquez, A. P. Mughari, M. Martínez Galera, Application of solid-phase microextraction for determination of pyrethroids in groundwater using liquid chromatography with post-column photochemically-induced fluorimetry derivatization and fluorescence detection. $J$ Chromatogr. A, 1188, 61-68 (2008).

[13] R. R. Naidu, R. V. P. Raju, Spectrophotometric determination of fenvalerate in a commercial formulation and as residues in water and soil. Pestic. Sci. 44, 163-166 (1995).

[14] U. Tamrakar, V. K. Gupta, A. K. Pillai, A spectrophotometric method for the determination of fenvalerate and cypermethrin in presence of each other. J. Anal. Chem. 67, 437-442 (2012).

[15] C. C. Sri, S. K. Shukla, P. N. Sarma, Highly Sensitive and Specific Tandem Mass Spectrometric Flow Injection method for the Identification of Pyrethroids. J. Flow Injection Anal. 25, 20-23 (2008).

[16] A. Coly, J.-J. Aaron, Flow Injection Analysis Determination of Several Aromatic Pesticides Using Fluorescence and Photo-induced Fluorescence Detection. Analusis 24, 107-112 (1996).

[17] A. Coly, J.-J. Aaron, Cyclodextrin-enhanced fluorescence and photochemically-induced fluorescence determination of five aromatic pesticides in water. Anal. Chim. Acta 360, 129-141 (1998).

[18] N. Maniasso, E. A. Zagatto, S. Reis, S. J. Santos, J. L. Lima, Exploitation of micellar medium for pho- tochemical-spectrofluorimetric flow-injection determination of fenvalerate. Lab Autom. Inf. Manage 34, 143-148 (1999).

[19] D. Zang, M. Yan, P. Zhao, L. Ge, S. Liu, J. Yu, A novel high selectivity chemiluminescence sensor for fenvalerate based on double-sided hollow molecularly imprinted materials. Analyst 137, 42474253 (2012).

[20] P. Khan, D. Idrees, M. A. Moxley, J. A. Corbett, F. Ahmad, G. von Figura, W. S. Sly, A. Waheed, M. Imtaiyaz Hassan, Luminol-Based Chemiluminescent Signals: Clinical and Nonclinical Application and Future Uses. Appl. Biochem. Biotechnol. 173, 333-355 (2014).

[21] P. A. Sundari, P. Manisankar, Development of Nano Poly (3-methyl thiophene)/Multiwalled Carbon Nanotubes Sensor for the Efficient Detection of Some Pesticides. J. Braz. Chem. Soc. 22, 746755 (2011).

[22] A. Coly, J.-J. Aaron, Photochemically-induced fluorescence determination of sulfonylurea herbicides using micellar media. Talanta 49, 107-117 (1999).

[23] J. J. Santana Rodriguez, R. Halko, J. R. Betancort Rodriguez, J.-J. Aaron, Environmental analytical applications of luminescence in organized supramolecular systems, Anal. Bioanal. Chem. 385, 525-545 (2006).

[24] T. Vega Morales, S. Montesdeoca Esponda, J. J. Santana Rodriguez, S. Efremova Aaron, J.-J. Aaron, Luminescence methods for study and determination of pollutants in the environment. Maced. J. Chem. Chem. Engin. 29, 1-42 (2010).

[25] M. Mbaye, M. D. Gaye Seye, A. Coly, A. Tine, J.J. Aaron, Usefulness of cyclodextrin media for the determination of $\alpha$-cypermethrin by photochemically-induced fluorescence. Analytical applications to natural waters. Anal. Bioanal. Chem. 394, 1089-1098 (2009).

[26] J.-J. Aaron, A. Coly, Photochemical-Spectrofluorimetric Determination of Two Pyrethroid Insecticides Using an Anionic Micellar Medium. Analyst 121, 1545-1549, (1996).

[27] A. Coly, J.-J. Aaron, Photochemical-spectrofluorimetric method for the determination of several aromatic insecticides. Analyst 119, 1205-1209 (1994). 